\title{
Glycerol and mixture of carbon sources conversion to hydrogen by Clostridium beijerinckii DSM791 and effects of various heavy metals on hydrogenase activity
}

\author{
Karen Trchounian ${ }^{a, b, c, *}$, Nicolai Müller ${ }^{a}$, Bernhard Schink ${ }^{a}$, \\ Armen Trchounian ${ }^{b, c}$ \\ a Department of Microbial Ecology, Limnology and General Microbiology, University of Konstanz, 78464, Konstanz, \\ Germany \\ ${ }^{\mathrm{b}}$ Department of Biochemistry, Microbiology and Biotechnology, Yerevan State University, 0025 Yerevan, Armenia \\ c Scientific-Research Institute of Biology, Yerevan State University, 0025 Yerevan, Armenia
}

Keywords:

Fermentation

Hydrogen production

Glycerol and mixed carbon sub-

strates

$\mathrm{pH}$

Hydrogenases

Clostridium beijerinckii

\begin{abstract}
A B S T R A C T
Hydrogen is a carbon-neutral energy feedstock which is produced during fermentation of various carbon sources. The genomes of clostridia encode mainly [Fe-Fe]-hydrogenases. Clostridium beijerinckii DSM791 performed anaerobic fermentation of glycerol in batch culture at $\mathrm{pH} 7.5$ and $\mathrm{pH} 5.5$ and produced $\mathrm{H}_{2}$. At pH 7.5, the glycerol consumption rate was $3.7 \mathrm{~g} / \mathrm{g}$ cell mass $/ \mathrm{h}$, which was higher than that at $\mathrm{pH} 5.5 . \mathrm{H}_{2}$ production reached $5 \mathrm{mmol} / \mathrm{h} /$ $\mathrm{g}$ cell mass at $\mathrm{pH}$ 7.5. The specific hydrogenase activity was $\sim 1.4$ fold higher if cells were grown on glycerol compared to cells grown on glucose. Single $\left(\mathrm{Fe}^{2+}, \mathrm{Fe}^{3+}, \mathrm{Ni}^{2+}\right)$ or mixed supply of metals $\left(\mathrm{Fe}^{2+}\right.$ and $\left.\mathrm{Ni}^{2+}\right)$ increased the specific hydrogenase activity by $\sim 50 \%$. These results suggest that $C$. beijerinckii DSM791 could be used as a potential $\mathrm{H}_{2}$ producer. It may help to further enhance $\mathrm{H}_{2}$ production using different industrial or agricultural wastes where glycerol and other carbon sources are present.
\end{abstract}

๑) 2017 Hydrogen Energy Publications LLC. Published by Elsevier Ltd. All rights reserved.

\section{Introduction}

Global warming, pollution caused by use of fossil fuels, along with a substantial reduction of natural gas and oil anticipates the exploration of clean and renewable energy sources. One of these sources might be dihydrogen $\left(\mathrm{H}_{2}\right)$ which has the highest energy density per mass among known fuels (142 MJ/ $\mathrm{kg}$ ) and can be produced by diverse microbes or other organisms $[1,2] . \mathrm{H}_{2}$ is a promising alternative energy carrier as it is 'eco-friendly' and its combustion generates only water.

\footnotetext{
* Corresponding author. Department of Biochemistry, Microbiology and Biotechnology, Yerevan State University, 0025 Yerevan, Armenia.

E-mail address: k.trchounian@ysu.am (K. Trchounian).
} 
Conversion of sugars, glycerol or miscellaneous organic carbon-containing industrial or agricultural wastes to $\mathrm{H}_{2}$ either by dark- or photo-fermentation has been established, and the description and engineering of these bioprocesses have already been developed $[3,4]$. Co-utilization of diverse carbon sources by various bacteria has been studied extensively [5-8] but the ability of microorganisms to produce $\mathrm{H}_{2}$ from different carbon sources and their mixtures is less clear, and therefore investigations to identify cheap and effective carbon sources that drive $\mathrm{H}_{2}$ production are highly pertinent.

Glycerol fermentation by Clostridium pasteurianum was reported more than two decades ago [9], and the main fermentation end products were butanol, 1,3-propanediol (1,3-PDO), ethanol, and acetic acid. Various strains of clostridia were isolated and investigated for glycerol fermentation to 1,3-PDO as this product is widely used in the synthetic chemical industry $[10,11]$. With increasing industrial production of biodiesel, glycerol as the main side product (about 10\% w/w) $[12,13]$ becomes an interesting and very cheap source for production of valuable chemicals $[14,15]$. For this purpose, many bacterial strains have been tested that ferment glycerol and produce organic acids, ethanol, or $\mathrm{H}_{2}$. Among them is Escherichia coli, which has been shown to ferment glycerol at both acidic [16-18] and alkaline [19] pHs. Crude and pure glycerol gave the same results $[20,21]$. Moreover, recently thermodynamic analysis of $\mathrm{H}_{2}$ production from crude glycerol using $\mathrm{C}$. pasteurianum was done [22]. Currently, development of $\mathrm{H}_{2}$ production technology focuses on the use of inexpensive substrates for producing valuable fuels and chemicals from various organic acids such as formate, lactate or sugars like lactose or xylose, which can be found in miscellaneous industrial or agricultural wastes $[23,24]$.

Most of the investigations of glycerol fermentation by clostridia have concentrated on butanol, butyrate or 1,3PDO production pathways and further engineering of the strains for enhanced generation of these compounds $[11,25,26]$. Recently, due to the demand for alternative clean energy sources, several clostridial strains (Clostridium butyricum, Clostridium felsineum, C. pasteurianum, Clostridium beijerinckii) were tested for production of $\mathrm{H}_{2}$ [27-29]. $\mathrm{H}_{2}$ generation was examined mainly using glucose or organic acids as substrates $[28,30]$. Several investigations were done with newly isolated Clostridium strains (C. pasteurianum $\mathrm{CH} 4$ ) for $\mathrm{H}_{2}$ production during glycerol fermentation, and further optimization of some external parameters like $\mathrm{pH}$, temperature, and agitation rate were analyzed $[28,31]$. The same strain was employed also for enhanced bio-butanol production [32]. In addition, it was shown that Clostridium $\mathrm{BOH}_{3}$ can be used for fermentation of agricultural residues and production of $\mathrm{H}_{2}$ [33].

$\mathrm{H}_{2}$ is produced by hydrogenase (Hyd) enzymes which reversibly oxidize $\mathrm{H}_{2}$ to $2 \mathrm{H}^{+}$. Different strains of clostridia have [Fe-Fe] and/or [Ni-Fe] Hyd enzymes [34]. Moreover, formate dehydrogenase (FDH) is present in some Clostridium strains (C. pasteurianum, C. beijerinckii) but limited information is available on whether a formate hydrogenlyase (FHL) -type reaction might be involved in hydrogen production by these bacteria [34].
The main goal of the present work, therefore, was to study the ability of $\mathrm{C}$. beijerinckii to convert glycerol to $\mathrm{H}_{2}$. Moreover, the effects of $\mathrm{pH}$ and of mixtures of various carbon sources on Hyd activity and $\mathrm{H}_{2}$ production were investigated. In addition, single or mixtures of different metals were employed to analyze whether they increase Hyd enzyme activity and thus $\mathrm{H}_{2}$ production. This would be important for the use of crude or pure glycerol, or of glucose- and formate-containing wastes for $\mathrm{H}_{2}$ evolution and further development of $\mathrm{H}_{2}$ production biotechnology.

\section{Materials and methods}

\section{Bacterial strain and growth conditions}

The type strain of C. beijerinckii DSM791 (identical to ATCC25752) was obtained from the German culture collection of microorganisms and cell cultures (DSMZ, Germany).

The growth medium was prepared according to DiezGonzalez et al. [35] with modifications. It contained (per L): $1.5 \mathrm{~g} \mathrm{~K}_{2} \mathrm{HPO}_{4} ; 1.5 \mathrm{~g} \mathrm{KH}_{2} \mathrm{PO}_{4} ; 492 \mathrm{mg} \mathrm{MgSO}{ }_{4}^{*} 7 \mathrm{H}_{2} \mathrm{O} ; 500 \mathrm{mg} \mathrm{L}-$

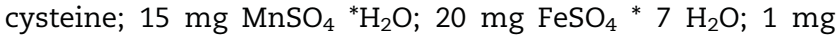
resazurin; $2 \mathrm{mg}$ p-aminobenzoic acid; $2 \mathrm{mg}$ thiamine- $\mathrm{HCl}$; $0.4 \mathrm{mg}$ biotin; $0.5 \mathrm{~g}$ yeast extract. The $\mathrm{pH}$ was adjusted to 7.5 or 5.5 by $2 \mathrm{~N} \mathrm{NaOH}$ or $2 \mathrm{~N} \mathrm{H}_{3} \mathrm{PO}_{4}$. The medium headspace was flushed with nitrogen and the medium was autoclaved at $121^{\circ} \mathrm{C}$ for $25 \mathrm{~min}$. Cells were grown with different individual carbon sources or mixtures thereof: glucose $-40 \mathrm{mM}$, formate - $10 \mathrm{mM}$, glycerol - $110 \mathrm{mM}$.

Batch fermentations of bacteria were carried out in $120 \mathrm{ml}$ sealed serum bottles containing $40 \mathrm{ml}$ medium incubated at $37^{\circ} \mathrm{C}$ during $96 \mathrm{~h}$.

\section{Preparation of cell-free extracts}

Cultures were grown in $500 \mathrm{ml}$ medium at $37^{\circ} \mathrm{C}$ for $22-24 \mathrm{~h}$ and harvested in an anoxic chamber (Coy, Ann Arbor, MI, USA) by centrifuging in anoxic polypropylene centrifuge bottles at $16,270 \times \mathrm{g}$ for $10 \mathrm{~min}$ at $4{ }^{\circ} \mathrm{C}$ using a Sorvall RC $5 \mathrm{~B}$ centrifuge (Du Pont de Nemours, Bad Homburg, Germany). Cells were washed and re-suspended in anoxic phosphate buffer (50 mM, pH 7.5) and centrifuged as described [36]. The pellet was re-suspended in $5 \mathrm{ml}$ of washing buffer, and the cells were broken by repeated passage through a cooled French-pressure cell at $137 \mathrm{MPa}$ pressure under anoxic conditions.

\section{Enzyme assays}

Enzyme activities were measured by following absorption changes with a Jenway 6300 spectrophotometer (Bibby Scientific, Staffordshire, UK) connected to an analogous recorder SE 120 (Metrawatt, BBC Goerz, Vienna, Austria). Assays were performed under anoxic conditions in $1 \mathrm{ml}$ rubber-stoppered cuvettes at $37^{\circ} \mathrm{C}$. One unit of specific enzyme activity was defined as $1 \mu \mathrm{mol}$ of substrate or product per minute at $37^{\circ} \mathrm{C}$ and per milligram of protein.

FDH enzyme activity was determined, as formate dependent benzyl viologen (BV) reduction [36,37]. The assay was 
done with $10-50 \mu \mathrm{l}$ cell-free extract; the reaction was initiated by adding $25 \mathrm{mM}$ sodium formate. One unit of formate dehydrogenase enzyme activity is defined as the reduction of $1 \mu \mathrm{mol}$ of BV per min. Hyd enzyme activity $\left(\mathrm{H}_{2}\right.$-dependent reduction of $\mathrm{BV}$ ) was determined, as described [36,38], except that the buffer used was $50 \mathrm{mM}$ phosphate buffer, $\mathrm{pH}$ 7.5. The reaction was started by adding $10-50 \mu \mathrm{l}$ cell-free extract. One unit of Hyd enzyme activity corresponded to the oxidation of $1 \mu \mathrm{mol}$ of $\mathrm{H}_{2}$ per min.

The wavelength used was $578 \mathrm{~nm}$ and an $E_{M}$ value of $8.600 \mathrm{M}^{-1} \mathrm{~cm}^{-1}$ was assumed for reduced BV.

\section{Analytical methods}

Gas samples were taken from the headspace of sealed serum bottles and $\mathrm{H}_{2}$ gas production was analyzed by gas chromatography (GC) with a GC 6000 (Carlo Erba, Milan, Italy) using a thermal conductivity detector, as described $[36,39]$. The carrier gas was nitrogen. $\mathrm{H}_{2}$ production rate was calculated as $\mathrm{mmol} /$ per hour/per g cell mass ( $\mathrm{mmol} / \mathrm{h} / \mathrm{g}$ cell mass). Organic compounds such as glucose, glycerol, ethanol, butanol, acetate etc. were measured by high-performance liquid chromatography (HPLC). Samples and standards were prepared by acidification with $\mathrm{H}_{2} \mathrm{SO}_{4}$ at a final concentration of $91 \mathrm{mM}$ followed by centrifugation for $5 \mathrm{~min}$ at $16,100 \times \mathrm{g}$ to remove cells. The supernatant was used for analysis and applied to the HPLC system with a 234 auto-injector (Gilson, Limburg-Offheim, Germany). Samples were separated at $60^{\circ} \mathrm{C}$ with an Aminex HPX-87H ion-exchange resin (BioRad, Munich, Germany) using an isocratic mobile phase of $5 \mathrm{mM} \mathrm{H}_{2} \mathrm{SO}_{4}$ at a flow rate of $0.6 \mathrm{ml} / \mathrm{min}$ provided by a LC-10AT vp pump (Shimadzu, Munich, Germany). Organic compounds were detected with a refractive index detector RID-10A (Shimadzu, Munich, Germany) and the detector signal was recorded with the Shimadzu LC solution software.

The cell density was determined by measuring optical density at $600 \mathrm{~nm}$ wavelength $\left(\mathrm{OD}_{600}\right)$ using a tube spectrophotometer M107 (Camspec Analytical Instruments Ltd., Leeds, UK). Calculations of cell mass were done, as cell dry weight of $\mathrm{OD}=1$ value corresponds to $1 \mathrm{~g}$ of dry cells using a predetermined correlation between optical density at $600 \mathrm{~nm}$ wavelength and cell dry weight [40].

Protein concentrations were determined with the Bradford method [41] with bovine serum albumin as a standard.

\section{Chemicals and data processing}

All chemicals were of analytical or reagent grade quality and obtained from Carl Roth (Karlsruhe, Germany) or Sigma-Aldrich (Deisenhofen, Germany). Gases were obtained from Messer-Griesheim (Darmstadt, Germany), and Sauerstoffwerke Friedrichshafen (Friedrichshafen, Germany).

Experiments were performed at least three times and each time in triplicate. Data are presented as standard deviation of the mean and were highly reproducible with generally not more than 3\% deviation. The validity of differences between experimental and control data was evaluated by Student's criteria (p) $[7,18]$; the difference is valid when $p<0.01$ or less, otherwise $p$ was represented, and $p>0.5$ if the difference is not valid.

\section{Results and discussion}

\section{Comparison of $\mathrm{H}_{2}$ production by Clostridium beijerinckii} during fermentation of glycerol and carbon source mixtures

To investigate whether $C$. beijerinckii growing on glycerol at different pHs (Fig. 1) is able to convert it to $\mathrm{H}_{2}$, initially $110 \mathrm{mM}$ glycerol was used. For comparison, glucose and various mixtures of carbon sources like glucose plus formate, glycerol plus formate and glucose plus glycerol were also analyzed to test if it is possible to enhance the $\mathrm{H}_{2}$ production and increase Hyd enzyme activity by using different carbon source combinations. The latter were of importance as in nature usually no single carbon source is present. C. beijerinckii grew better on glycerol at $\mathrm{pH} 7.5$ compared to $\mathrm{pH}$ 5.5. This might be due to optimal enzyme activity especially a high ATPase activity as well as keeping of neutral intracellular $\mathrm{pH}$ and maintaining a higher proton-motive force at high but not low $\mathrm{pH}$; further study is required. This is likely to that the intracellular $\mathrm{pH}$ and transmembrane $\mathrm{pH}$ gradient follow medium $\mathrm{pH}$, as shown for Clostridium acetobutilicum [42], and induction of some operons for global regulators and hydrogenases when the protonATPase activity is higher at high but not low $\mathrm{pH}$, as shown for E. coli $[43,44]$.

The $\mathrm{H}_{2}$ production rate during fermentation of glycerol at $\mathrm{pH} 7.5$ was $\sim 3.5 \mathrm{mmol} / \mathrm{h} / \mathrm{g}$ cell mass, which was $\sim 1.2$ fold lower

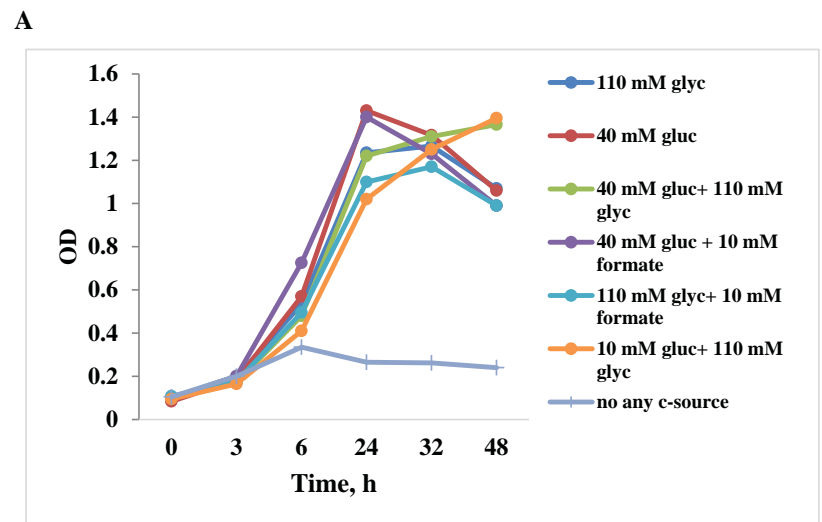

B

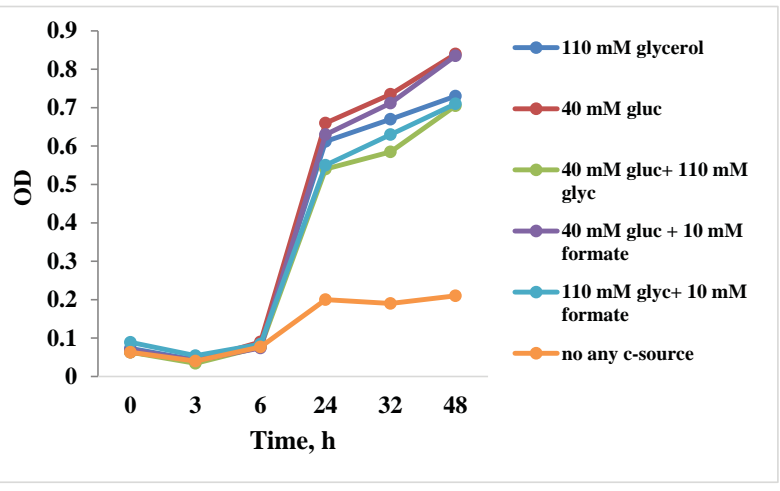

Fig. 1 - Growth of C. beijerinckii DSM791 at $37{ }^{\circ} \mathrm{C}$ at pH 7.5 (A) and pH 5.5 (B) during utilization of various carbon sources. For details see "Materials and methods". 


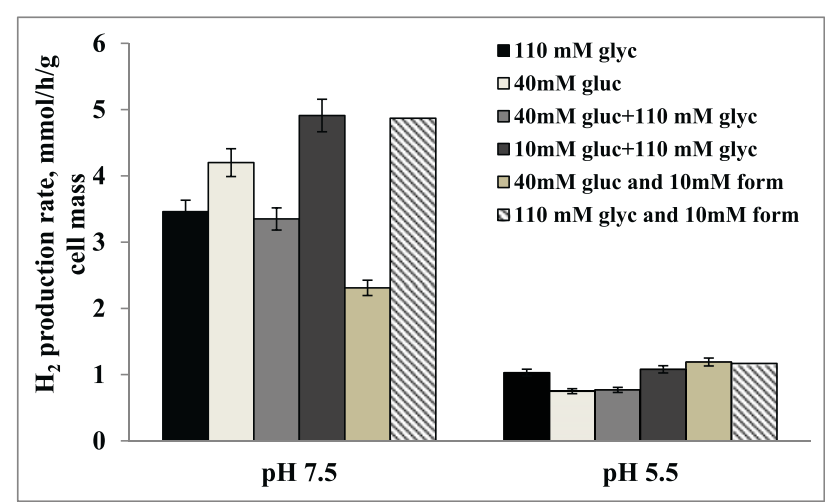

Fig. $2-\mathrm{H}_{2}$ production rate by whole cells of $\mathrm{C}$. beijerinckii DSM791 grown at pH 7.5 or pH 5.5 during utilization of single or mixtures of carbon sources. For details see "Materials and methods".

compared to growth with glucose (Fig. 2). The $\mathrm{H}_{2}$ yield was $1.21 \mathrm{~mol} \mathrm{H}_{2} / \mathrm{mol}$ glycerol (Table 1) which was in the same range (1.11 $\mathrm{mol} \mathrm{H}_{2} / \mathrm{mol}$ glycerol) as shown for C. pasteurianum CH4 by Lo et al., [28]. But interestingly, a mixture of $110 \mathrm{mM}$ glycerol and $10 \mathrm{mM}$ formate increased the rate by $\sim 1.4$ fold compared to glycerol only. With a mixture of $40 \mathrm{mM}$ glucose plus $10 \mathrm{mM}$ formate, the $\mathrm{H}_{2}$ production rate was decreased $\sim 1.8$ fold (see Fig. 2). At $\mathrm{pH} 5.5$, the $\mathrm{H}_{2}$ production rate was lower in all variations of single or mixed carbon sources. In general, during glycerol fermentation the $\mathrm{H}_{2}$ production rate at pH 5.5 was $1 \mathrm{mmol} / \mathrm{h} / \mathrm{g}$ cell mass and 3.4 fold lower than at $\mathrm{pH} 7.5$ (see Fig. 2). During glucose fermentation at this $\mathrm{pH}$, the $\mathrm{H}_{2}$ production rate was lower compared to glycerol (see Fig. 2). It is important to mention that many groups isolated various strains and tested for $\mathrm{H}_{2}$ production [29,32,45-47] but they used different medium composition and various conditions ( $\mathrm{pH}$, temperature, agitation etc.) that is why it is difficult to compare results with other data. Especially, Lin et al. [29] showed that $\mathrm{C}$. beijerinckii L9 can produce $\mathrm{H}_{2}$ from glucose (2.81 $\mathrm{mol} \mathrm{H}_{2} /$ mol-glucose), C. beijerinckii Fanp3 (2.52 $\mathrm{mol} \mathrm{H}_{2}$ / mol-glucose) [45]. Masset et al. [46] showed that $C$. butyricum CWBI1009 also produced $\mathrm{H}_{2}$ from glucose $\left(1.69 \mathrm{~mol} \mathrm{H}_{2} / \mathrm{mol}\right.$ glucose). In our studies C. beijericnkii DSM 791 yielded $2.5 \mathrm{~mol}$ $\mathrm{H}_{2} /$ mol glucose. Recently, Morra et al. [47] reported that newly isolated C. beijerinckii strain has high $\mathrm{H}_{2}$ production rate from vegetable wastes. Moreover, the conversion efficiency of $\mathrm{H}_{2}$ produced from glycerol is $17.70 \%$ calculated as described [45]; the lower heating value of glycerol is $14,300 \mathrm{~kJ} / \mathrm{kg}$. This data are in the same range (16.7\%) as shown for C. beijerinckii FanP3 during glucose fermentation [45]. This value means that glycerol can be competitive with glucose. Taken together it might be concluded that many strains are isolated and tested for $\mathrm{H}_{2}$ production and stated that they are good $\mathrm{H}_{2}$ producers. But to choose effective strains to obtain higher yields of $\mathrm{H}_{2}$ generation and be dominant in large scale applications external conditions should be further optimized.

Fermentation products generated during growth on glycerol and various carbon source mixtures

To understand the differences in $\mathrm{H}_{2}$ production and possible effects of fermentation end products on $\mathrm{H}_{2}$ metabolism, soluble products were determined after growth at different pHs. During glycerol fermentation at $\mathrm{pH} 7.5$, the main products were 1,3-propanediol (1,3-PDO) and butyrate (Fig. 3A). These data are in good agreement with results previously shown for C. pasteurianum $[24,25]$. Besides the main metabolites, acetate $(\sim 9 \mathrm{mM})$, formate $(\sim 8 \mathrm{mM})$ and lactate $(\sim 1 \mathrm{mM})$ were also generated. Interestingly, $110 \mathrm{mM}$ glycerol was completely consumed during $48 \mathrm{~h}$. These data were of interest since different data with glycerol consumption concentration and duration have been reported for different clostridia by different groups $[25,48]$.

During glucose fermentation, the main metabolites produced were acetate and butyrate but not 1,3-PDO (Fig. 3B); among other products were formate and lactate. When cells were cultivated with a mixture of glucose $(40 \mathrm{mM})$ and glycerol (110 mM) cells consumed glycerol simultaneously with glucose (Fig. 3C), and thus did not exhibit diauxic growth $[45,46]$. The main products were again 1,3-PDO and butyrate (see Fig. 3C), and also acetate. Only in the mixture of the above-mentioned carbon sources was ethanol detected. The fermentation end products formed are mainly in good correlation with the data from other groups $[26,32,45,47]$. The mixture of glucose $(10 \mathrm{mM})$ and glycerol $(110 \mathrm{mM})$ showed the same results as under the previous conditions with the mixture of glucose and glycerol. Also in this case, glycerol was utilized simultaneously with glucose (Fig. 3D). At pH 5.5 during fermentation of glycerol or glucose or the mixtures after $96 \mathrm{~h}$, the carbon sources were not consumed completely by $\mathrm{C}$. beijerinckii. The main product was again 1,3-PDO. Butyrate was also formed.

\section{Hydrogenase activity of C. beijerinckii after fermentation of different carbon sources}

To understand the role of Hyd enzymes in $\mathrm{H}_{2}$ production during fermentation of different substrates and their mixtures, Hyd activity was determined. In all tested conditions

Table 1 - Comparison of $\mathrm{H}_{2}$ yield values by different clostridia during conversion of glycerol as a carbon source.

\begin{tabular}{|c|c|c|c|c|}
\hline Strain & Operation mode & $\begin{array}{c}\text { Pure glycerol } \\
\text { concentration (mM) }\end{array}$ & $\begin{array}{l}\mathrm{H}_{2} \text { yield }\left(\mathrm{mol} \mathrm{H}_{2} /\right. \\
\text { mol glycerol) }\end{array}$ & References \\
\hline Clostridium butyricum LMG1212t2 & Batch & 110 & 0.55 & [38] \\
\hline Clostridium pasteurianum $\mathrm{CH} 4$ & Batch & 110 & 1.11 & [24] \\
\hline C. pasteurianum LMG3285 & Batch & 110 & 0.6 & [38] \\
\hline Enterobacter aerogenes & Batch & 20 & 1.12 & [39] \\
\hline Clostridium beijerinckii DSM791 & Batch & 110 & 1.21 & This study \\
\hline
\end{tabular}





Fig. 3 - Fermentation end products of C. beijerinckii DSM791 grown at pH 7.5 during fermentation of glycerol (A), glucose (B), glucose $(40 \mathrm{mM})$ and glycerol $(110 \mathrm{mM})(C)$, glucose $(10 \mathrm{mM})$ and glycerol $(110 \mathrm{mM})(\mathrm{D})$. For details see "Materials and methods".

the Hyd activity was higher at $\mathrm{pH} 7.5$ than at $\mathrm{pH}$ 5.5. The optimal Hyd activity at high $\mathrm{pH}$ can be linked to higher ATPase activity and maintaining of higher proton-motive force. This is likely to that the Hyd activity in E. coli is interrelated with the proton ATPase activity and maintaining of proton-motive force at high $\mathrm{pH}$ [49] and the proton-ATPase activity is higher at high but not low $\mathrm{pH}$ [43]. It is of interest that the role of hydrogenases in proton motive force generation was shown for Clostridium acetobutylicum [50].
When cells were grown at pH 7.5 on glucose, the Hyd activity was $\sim 3.3$ fold higher than at pH 5.5 (Fig. 4). In C. butyricum grown at pH 6.5 during fermentation of glucose the Hyd specific activity was $4.8 \mathrm{U} / \mathrm{mg}$ which was $~ 1.8$ fold lower when the cells were grown on glucose and glycerol [51]. Moreover, at pH 7.5 , Hyd activity of the cells grown on glycerol was $\sim 1.4$ fold higher than cells grown at the same $\mathrm{pH}$ on glucose. Interestingly, cells grown in the presence of glycerol plus formate at pH 7.5 showed increased Hyd activity compared to cells grown

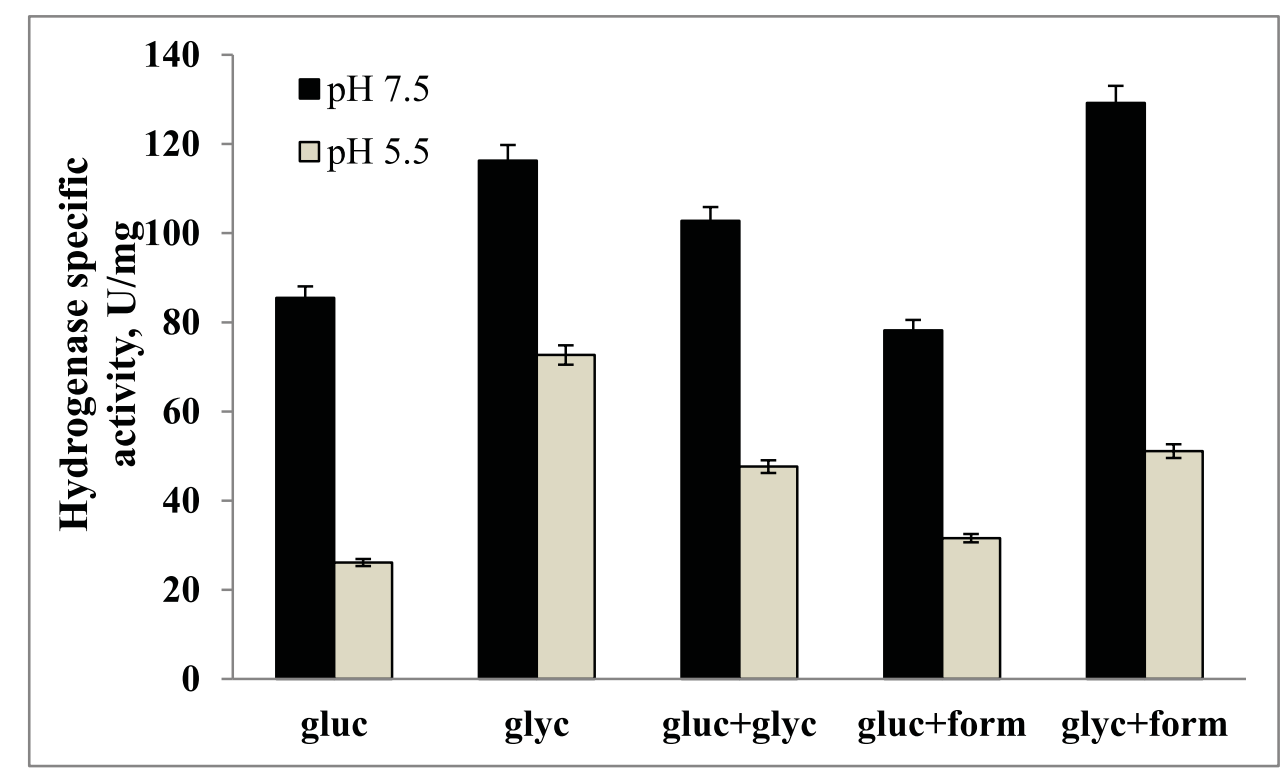

Fig. 4 - Hydrogenase activity in cell free extracts of C. beijerinckii DSM791 grown at pH 7.5 and pH 5.5 in the presence of various carbon sources. Cells were grown in the presence of $40 \mathrm{mM}$ glucose (glu), $110 \mathrm{mM}$ glycerol (glyc), $40 \mathrm{mM}$ glucose plus $110 \mathrm{mM}$ glycerol (gluc+glyc), $40 \mathrm{mM}$ glucose plus $10 \mathrm{mM}$ formate (gluc+form), $110 \mathrm{mM}$ glycerol plus $10 \mathrm{mM}$ formate (glyc+form). For details see "Materials and methods". 
at pH 5.5. From these data it is suggested that optimal Hyd enzyme activity is determined at high $\mathrm{pH}$.

Effects of various heavy metals on Hyd activity by C. beijerinckii

To reveal the role of heavy metals on Hyd activity effects of various metals $\left(\mathrm{Fe}^{2+}, \mathrm{Fe}^{3+}, \mathrm{Ni}^{2+}\right)$ were studied. These metals might affect activity of [Ni-Fe] or [Fe-Fe] Hyd enzymes [52]. Indeed, in cells grown on glucose at $\mathrm{pH} 7.5$, Hyd enzyme activity was increased $\sim 1.3$ fold if $0.1 \mathrm{mM} \mathrm{Fe}^{3+}$ was added in the assays (Fig. 5A). No effect was observed for $\mathrm{Fe}^{2+}$ at any concentration.

When the cells were grown at $\mathrm{pH} 7.5$ on glycerol plus formate the addition of $\mathrm{Fe}^{2+}(0.01 \mathrm{mM})$ stimulated Hyd activity by $\sim 1.3$ fold. The same effect was obtained when $\mathrm{Fe}^{3+}$ $(0.5 \mathrm{mM})$ or $\mathrm{Ni}^{2+}(1 \mu \mathrm{M})$ was added in the assays (see Fig. $5 \mathrm{~A}$ and $\mathrm{B})$. As the results above showed that single $\mathrm{Fe}^{2+}$ $(0.01 \mathrm{mM})$ and $\mathrm{Ni}^{2+}(1 \mu \mathrm{M})$ increased Hyd activity the mixture of these metals in the same concentrations were studied, and Hyd activity was increased by $~ 50 \%$ compared to the cellfree extracts only or by $\sim 25 \%$ compared to the assays with single metals (Fig. 6).

The same assays were performed at $\mathrm{pH} 5.5$ in the presence of different metals when cells were grown during fermentation of single or mixed carbon sources. In general, no stimulatory effects were observed with any of the metals in various

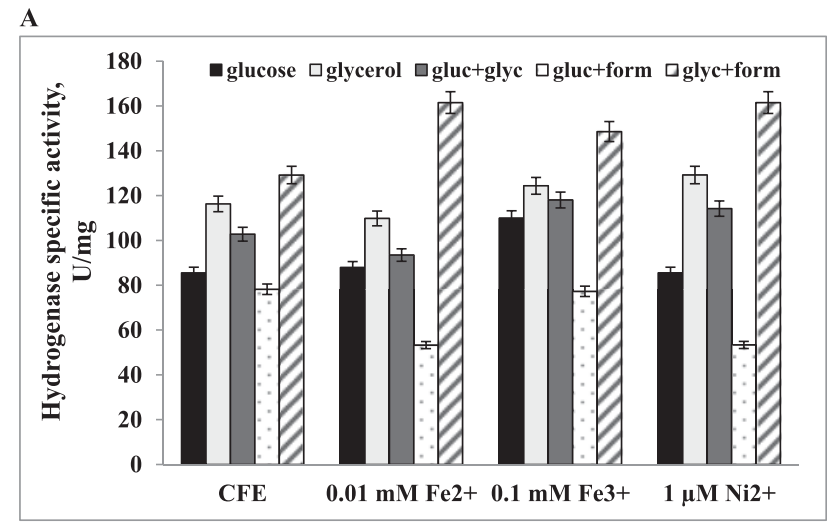

B

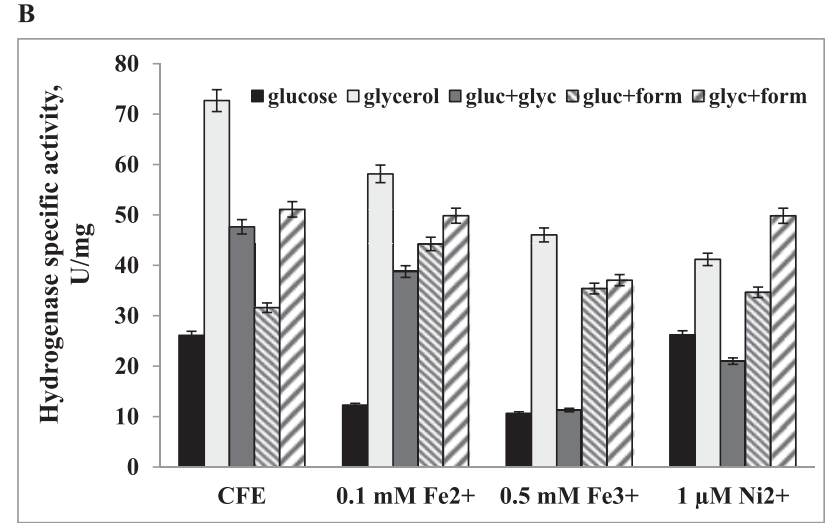

Fig. 5 - Hydrogenase activity of C. beijerinckii DSM791 grown at $\mathrm{pH} 7.5$ (A) and $\mathrm{pH} 5.5$ (B) in the presence of various carbon sources. In the assays different metals were added. For others see legends to Fig. 4.

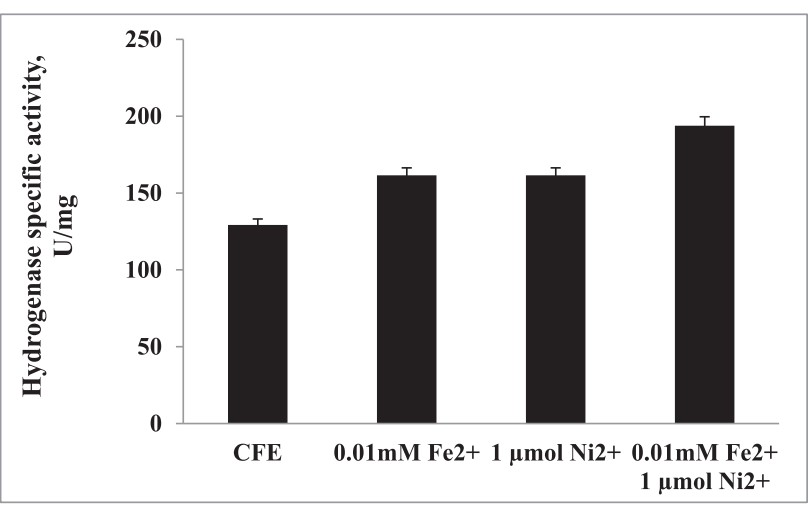

Fig. 6 - Hydrogenase activity in cell free extracts of $C$. beijerinckii DSM791 grown at pH 7.5 in the presence of glycerol and formate. In the assays single or mixtures of different metals $\left(\mathrm{Fe}^{2+}\right.$ and $\left.\mathrm{Ni}^{2+}\right)$ were added. For others see legends to Fig. 4.

concentrations. These results suggest that [Ni-Fe] and [Fe-Fe] hydrogenases are active in C. beijerinckii DSM791 at pH 7.5. Probably, they have a role in maintaining of proton motive force at this $\mathrm{pH}$. The effects of various metals on $\mathrm{H}_{2}$ production would be determined after optimization of the other conditions $(\mathrm{pH}$, concentration of carbon sources and their mixtures) in a separate study.

Formate dehydrogenase activity during fermentation of various mixtures of carbon sources

$\mathrm{H}_{2}$ can be produced from formate disproportionation by FHL; the latter consists of FDH and Hyd [53]. As Hyd activity was determined, it would be of interest to detect if FDH is active in the cells grown during fermentation of various single carbon sources or their mixtures. Indeed, in cells of C. beijerinckii grown on glycerol, glycerol plus formate, and glucose plus formate at pH 7.5, FDH activity was higher than that at pH 5.5 (Fig. 7). Moreover, FDH activity was increased by $~ 50 \%$ when the cells were grown on glycerol plus formate, compared to cells grown on glycerol only at pH 7.5 (see Fig. 7). The same

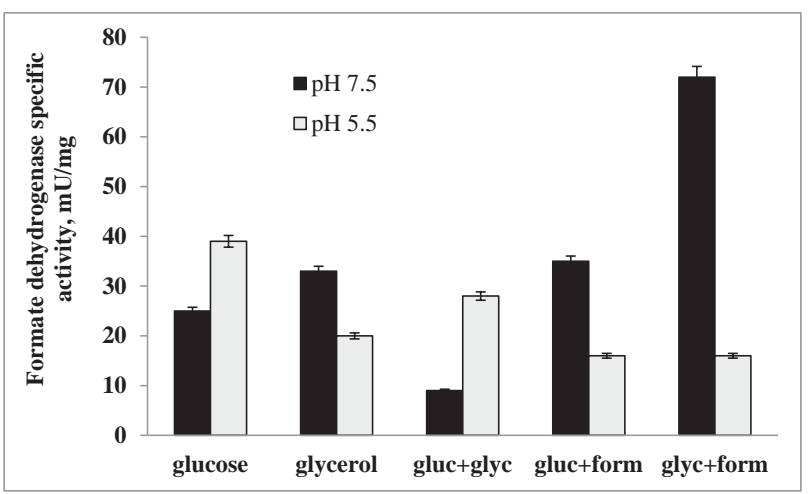

Fig. 7 - Formate dehydrogenase activity in cell free extracts of C. beijerinckii DSM791 grown at pH 7.5 and pH 5.5 in the presence of various carbon sources. For others see legends to Fig. 4. 
stimulatory effect of formate on FDH activity was observed when the cells were grown on glucose plus formate. But surprisingly, stimulation by formate was not observed at $\mathrm{pH} 5.5$. These results confirm the data obtained for Hyd activity that the cells showed FDH higher activity at pH 7.5 than at pH 5.5. This might explain less $\mathrm{H}_{2}$ production and lower consumption of glycerol or other carbon sources by $\mathrm{C}$. beijerinckii. Thus, FDH activity has been determined to depend on $\mathrm{pH}$ and carbon source, especially formate. As a substrate, formate might directly affect FDH and increase its activity. Besides, it could be suggested that FDH interacts with Hyd enzymes forming FHL complex at pH 7.5 which requires special study. This interaction might also affect FDH activity if any. The situation of FDH activity with $\mathrm{C}$. beijerinckii seems to be likely to that for E. coli when different FDH and its complexes with Hyd have been proposed [54].

\section{Conclusions and significance}

The results obtained point out that C. beijerinckii DSM791 is an effective strain for the conversion of glycerol to $\mathrm{H}_{2}$. Moreover, in the presence of sugar (glucose) this strain simultaneously utilized glycerol. At pH 7.5 glycerol utilization was higher compared to $\mathrm{pH} 5.5$, which had impact on Hyd enzyme activity. Adding a mixture of $0.1 \mathrm{mM} \mathrm{Fe}^{2+}$ and $1 \mu \mathrm{M} \mathrm{Ni}^{2+}$ increased the Hyd enzyme activity by $\sim 50 \%$ at $\mathrm{pH} 7.5$ when cells were grown in the presence of glycerol plus formate. The other important finding was that growth of $\mathrm{C}$. beijerinckii in a mixture of carbon sources used did not impair $\mathrm{H}_{2}$ production. This would be important when considering using the organic wastes resulting from the industrial scale production of biofuels.

\section{Acknowledgement}

The study was supported by German Academic Exchange Service (DAAD) (91572698) Fellowship to KT

\section{R E F E R E N C E S}

[1] Trchounian A. Mechanisms for hydrogen production by different bacteria during mixed-acid and photofermentation and perspectives of hydrogen production biotechnology. Crit Rev Biotechnol 2015;35:103-13.

[2] Hosseini SE, Wahid MA. Hydrogen production from renewable and sustainable energy resources: promising green energy carrier for clean development. Renew Sustain Energy Rev 2016;57:850-66.

[3] Sivagurunathan P, Kumar G, Bakonyi P, Kim SH, Kobayashi T, $\mathrm{Xu} \mathrm{KQ}$ et al. A critical review on issues and overcoming strategies for the enhancement of dark fermentative hydrogen production in continuous systems. Int J Hydrogen Energy 2016;41:3820-36.

[4] Hallenbeck PC, Liu Y. Recent advances in hydrogen production by photosynthetic bacteria. Int J Hydrogen Energy 2016:41:4446-54.

[5] Liu Y, Zhang YG, Zhang RB, Zhang F, Zhu J. Glycerol/glucose co-fermentation: one more proficient process to produce propionic acid by Propionibacterium acidipropionici. Curr Microbiol 2011;62:152-8.

[6] Thapa LP, Lee SJ, Yang XG, Yoo HY, Kim SB, Park C, et al. Co-fermentation of carbon sources by Enterobacteraerogenes ATCC 29007 to enhance the production of bioethanol. Bioprocess Biosyst Eng 2014;37:1073-84.

[7] Trchounian K, Trchounian A. Escherichia coli hydrogenase 4 (hyf) and hydrogenase 2 (hyb) contribution in $\mathrm{H}_{2}$ production during mixed carbon (glucose and glycerol) fermentation at pH 7.5 and $\mathrm{pH}$ 5.5. Int J Hydrogen Energy 2013;38:3921-9.

[8] Rollina JA, del Campoa JM, Myunga S, Sunb F, Youa C, Bakovic A, et al. High-yield hydrogen production from biomass by in vitro metabolic engineering: mixed sugars coutilization and kinetic modeling. Proc Nat Acad Sci U S A 2015. 201417719.

[9] Nakas JP, Schaedle M, Parkinson CM, Coonley CE, Tanenbaum SW. System development for linkedfermentation production of solvents from algal biomass. Appl Environ Microbiol 1983;46:1017-23.

[10] Homann T, Tag C, Biebl H, Deckwer WD, Schink B. Fermentation of glycerol to 1,3-propanediol by Klebsiella and Citrobacter strains. Appl Microbiol Biotechnol 1990;33:121-6.

[11] Wischral D, Zhang J, Cheng C, Lin M, De Souza LM, Pessoa FL, et al. Production of 1, 3-propanediol by Clostridium beijerinckii DSM 791 from crude glycerol and corn steep liquor: process optimization and metabolic engineering. Bioresour Technol 2016;212:100-10.

[12] Yen HW, Hu IC, Chen CY, Ho SH, Lee DJ, Chang JS. Microalgae based biorefinery - from biofuels to natural products. Bioresour Technol 2013:135:166-74.

[13] Mardhiah HH, Ong HC, Masjuki HH, Lim S, Lee HV. A review on latest developments and future prospects of heterogeneous catalyst in biodiesel production from nonedible oils. Renew Sustain Energy Rev 2017;67:1225-36.

[14] Clomburg JM, Gonzalez R. Anaerobic fermentation of glycerol: a platform for renewable fuels and chemicals. Trends Biotechnol 2013;31:20-8.

[15] Ghadiryanfar M, Rosentrater KA, Keyhani A, Omid M. A review of macroalgae production, with potential applications in biofuels and bioenergy. Renew Sustain Energy Rev 2016;54:473-81.

[16] Emde R, Swain A, Schink B. Anaerobic oxidation of glycerol by Escherichia coli in an amperometric poised-potential culture system. Appl Microbiol Biotechnol 1989;32:170-5.

[17] Dharmadi Y, Murarka A, Gonzalez R. Anaerobic fermentation of glycerol by Escherichia coli: a new platform for metabolic engineering. Biotechnol Bioeng 2006;94:821-9.

[18] Trchounian K, Sanchez-Torres V, Wood TK, Trchounian A. Escherichia coli hydrogenase activity and $\mathrm{H}_{2}$ production under glycerol fermentation at a low pH. Int J Hydrogen Energy 2011;36:4323-31.

[19] Trchounian K, Trchounian A. Hydrogenase 2 is most and hydrogenase 1 is less responsible for $\mathrm{H}_{2}$ production by Escherichia coli under glycerol fermentation at neutral and slightly alkaline pH. Int J Hydrogen Energy 2009;34:8839-45.

[20] Trchounian K, Trchounian A. Hydrogen production from glycerol by Escherichia coli and other bacteria: an overview and perspectives. Appl Energy 2015;156:174-84.

[21] San Kong P, Aroua MK, Daud WM. Conversion of crude and pure glycerol into derivatives: a feasibility evaluation. Renew Sustain Energy Rev 2016;63:533-55.

[22] Sarma S, Dubey VK, Moholkar VS. Kinetic and thermodynamic analysis (with statistical optimization) of hydrogen production from crude glycerol using Clostridium pasteurianum. Int J Hydrogen Energy 2016;41:19972-89.

[23] Rosales-Colunga LM, Razo-Flores E, De León Rodríguez A. Fermentation of lactose and its constituent sugars by 
Escherichia coli WDHL: impact on hydrogen production. Bioresour Technol 2012;111:180-4.

[24] Moreno R, Fierro J, Fernández C, Cuetos MJ, Gómez X. Biohydrogen production from lactose: influence of substrate and nitrogen concentration. Environ Technol 2015;36:2401-9.

[25] Biebl H. Fermentation of glycerol by Clostridium pasteurianum - batch and continuous culture studies. J Indust Microbiol Biotechnol 2001;27:18-26.

[26] Biebl H, Menzel K, Zeng A-P, Deckwer W-D. Microbial production of 1, 3-propanediol. Appl Microbiol Biotechnol 1999;52:289-97.

[27] Masset J, Calusinska M, Hamilton C, Hiligsmann S, Joris B, Wilmotte A, et al. Fermentative hydrogen production from glucose and starch using pure strains and artificial cocultures of Clostridium spp. Biotechnol Biofuels 2012;5:35.

[28] Lo YC, Chen XJ, Huang CY, Yuan YJ, Chang JS. Dark fermentative hydrogen production with crude glycerol from biodiesel industry using indigenous hydrogen-producing bacteria. Int J Hydrogen Energy 2013;38:15815-22.

[29] Lin PY, Whang LM, Wu YR, Ren WJ, Hsiao CJ, Li SL, et al. Biological hydrogen production of the genus Clostridium: metabolic study and mathematical model simulation. Int J Hydrogen Energy 2007;32:1728-35.

[30] Matsumoto M, Nishimura Y. Hydrogen production by fermentation using acetic acid and lactic acid. J Biosci Bioeng 2007;103:236-41.

[31] Liu IC, Whang LM, Ren WJ, Lin PY. The effect of pH on the production of biohydrogen by clostridia: thermodynamic and metabolic considerations. Int J Hydrogen Energy 2011;36:439-49.

[32] Lin DS, Yen HW, Kao WC, Cheng CL, Chen WM, Huang CC, et al. Bio-butanol production from glycerol with Clostridium pasteurianum $\mathrm{CH} 4$ : the effects of butyrate addition and in situ butanol removal via membrane distillation. Biotechnol Biofuels 2015;8:1.

[33] Gobinath R, He J, Yang KL. One-pot fermentation of agricultural residues to produce butanol and hydrogen by Clostridium strain $\mathrm{BOH}_{3}$. Renew Energy 2016;85:1127-34.

[34] Calusinska M, Happe T, Joris B, Wilmotte A. The surprising diversity of clostridial hydrogenases: a comparative genomic perspective. Microbiology 2010;156:1575-88.

[35] Diez-Gonzalez F, Russell JB, Hunter JB. The role of an NADindependent lactate dehydrogenase and acetate in the utilization of lactate by Clostridium acetobutylicum strain P262. Arch Microbiol 1995;164:36-42.

[36] Müller N, Griffin BM, Stingl U, Schink B. Dominant sugar utilizers in sediment of Lake Constance depend on syntrophic cooperation with methanogenic partner organisms. Environ Microbiol 2008;10:1501-11.

[37] Sawers RG, Ballantine SP, Boxer DH. Differential expression of hydrogenase isoenzymes in Escherichia coli $\mathrm{K}-12$ : evidence for a third isoenzyme. J Bacteriol 1985;164:1324-31.

[38] Ballantine S, Boxer DH. Nickel-containing hydrogenase isoenzymes from anaerobically grown Escherichia coli K-12. J Bacteriol 1985;163:454-9.

[39] Platen H, Schink B. Methanogenic degradation of acetone by an enrichment culture. Arch Microbiol 1987;149:136-41.

[40] Assobhei O, El Kanouni A, Ismaili M, Loutfi M, Petitdemange $\mathrm{H}$. Effect of acetic and butyric acids on the stability of solvent and spore formation by Clostridium acetobutylicum ATCC 824 during repeated subculturing. J Ferment Bioeng 1998;85:209-12.

[41] Bradford MM. A rapid and sensitive method for the quantitation of microgram quantities of protein utilizing the principle of protein-dye binding. Anal Biochem 1976;72:248-54.

[42] Millat T, Janssen H, Bahl H, Fischer RJ, Wolkenhauer O. Integrative modelling of $\mathrm{pH}$-dependent enzyme activity and transcriptomic regulation of the acetone-butanol-ethanol fermentation of Clostridium acetobutylicum in continuous culture. Microb Biotechnol 2013;6:526-39.

[43] Padan E, Bibi E, Ito M, Krulwich TA. Alkaline $\mathrm{pH}$ homeostasis in bacteria: new insights. BBA-Biomembr 2005;1717:67-88.

[44] Slonczewski JL, Fujisawa M, Dopson M, Krulwich TA. Cytoplasmic pH measurement and homeostasis in bacteria and archaea. Adv Microb Physiol 2009;55:1-317.

[45] Pan CM, Fan YT, Zhao P, Hou HW. Fermentative hydrogen production by the newly isolated Clostridium beijerinckii Fanp3. Int J Hydrogen Energy 2008;33:5383-91.

[46] Masset J, Hiligsmann S, Hamilton C, Beckers L, Franck F, Thonart P. Effect of $\mathrm{pH}$ on glucose and starch fermentation in batch and sequenced-batch mode with a recently isolated strain of hydrogen-producing Clostridium butyricum CWBI1009. Int J Hydrogen Energy 2010;35:3371-8.

[47] Morra S, Arizzi M, Allegra P, La Licata B, Sagnelli F, Zitella P, et al. Expression of different types of [FeFe]-hydrogenase genes in bacteria isolated from a population of a biohydrogen pilot-scale plant. Int J Hydrogen Energy 2014;39:9018-27.

[48] Heyndrickx M, Vos PD, Ley JD. Fermentation characteristics of Clostridium pasteurianum LMG 3285 grown on glucose and mannitol. J Appl Bacteriol 1991;70:52-8.

[49] Trchounian K, Pinske C, Sawers RG, Trchounian A. Dependence on the $\mathrm{F}_{0} \mathrm{~F}_{1}$-ATP synthase for the activities of the hydrogen-oxidizing hydrogenases 1 and 2 during glucose and glycerol fermentation at high and low pH in Escherichia coli. J Bioenerg Biomembr 2011;43:645-50.

[50] Girbal L, Vasconcelos I, Soucaille P. Transmembrane pH of Clostridium acetobutylicum is inverted (more acidic inside) when the in vivo activity of hydrogenase is decreased. J Bacteriol 1994;176:6146-7.

[51] Saint-Amans S, Girbal L, Andrade J, Ahrens K, Soucaille P. Regulation of carbon and electron flow in Clostridium butyricum VPI 3266 grown on glucose-glycerol mixtures. J Bacteriol 2001;183:1748-54.

[52] Peters JW, Schut GJ, Boyd ES, Mulder DW, Shepard EM, Broderick JB, et al. [FeFe]-and [NiFe]-hydrogenase diversity, mechanism, and maturation. BBA-Mol Cell Res 2015;1853:1350-69.

[53] Trchounian K, Poladyan A, Vassilian A, Trchounian A. Multiple and reversible hydrogenases for hydrogen production by Escherichia coli: dependence on fermentation substrate, $\mathrm{pH}$ and the $\mathrm{F}_{0} \mathrm{~F}_{1}$-ATPase. Crit Rev Biochem Mol Biol 2012;47:236-49.

[54] Andrews SC, Berks BC, McClay J, Ambler A, Quail MA, Golby P, et al. 12-cistron Escherichia coli operon (hyf) encoding a putative proton-translocating formate hydrogenlyase system. Microbiology 1997;143:3633-47. 